\title{
Islam, secularist government, and state-civil society interaction in Mozambique and South Africa since 1994
}

\author{
Kaarsholm, Preben
}

Published in:

Journal of Eastern African Studies

DOI:

10.1080/17531055.2015.1082255

Publication date:

2015

\section{Document Version}

Peer reviewed version

Citation for published version (APA):

Kaarsholm, P. (2015). Islam, secularist government, and state-civil society interaction in Mozambique and South Africa since 1994. Journal of Eastern African Studies, 9(3), 468-487.

https://doi.org/10.1080/17531055.2015.1082255

\section{General rights}

Copyright and moral rights for the publications made accessible in the public portal are retained by the authors and/or other copyright owners and it is a condition of accessing publications that users recognise and abide by the legal requirements associated with these rights.

- Users may download and print one copy of any publication from the public portal for the purpose of private study or research.

- You may not further distribute the material or use it for any profit-making activity or commercial gain.

- You may freely distribute the URL identifying the publication in the public portal.

Take down policy

If you believe that this document breaches copyright please contact rucforsk@kb.dk providing details, and we will remove access to the work immediately and investigate your claim. 


\title{
Islam, secularist government, and state-civil society interaction in Mozambique and South Africa since 1994
}

\author{
Preben Kaarsholm \\ Department of Society and Globalisation, Roskilde University, Roskilde, Denmark
}

\begin{abstract}
This article explores state-civil society interactions in Mozambique and South Africa with a focus on Islamic groupings, and places the two countries within an Indian Ocean coastal continuum of links to East Africa, India, and the Arab world. Contrasting the histories of dominant-party rule since the transitions in 1994 to multiparty-ism in Mozambique and to democracy in South Africa, the article discusses the development of Islamic organisations including both transnational Sufi orders and modernist reform movements as important components in local civil societies. The article contrasts the spaces for accommodation of Islamic groups that have been created in South Africa with the more radical secularism that has been in place in post-Independence Mozambique. Finally, the article discusses the effects of this contrast on possibilities for stability and democratic consolidation in the context of the 2014 elections in South Africa and Mozambique.
\end{abstract}

Keywords: Islam, secularism, state-civil society interaction, dominant-party states

The present article sets out to compare interactions between civil society and the state and more specifically between different forms of Islam and configurations of secularist government - in Mozambique and South Africa since 1994. It does so with a point of departure in recently conducted research, which has studied late 19th and 20th century Sufi networks stretching between Ilha de Moçambique, Maputo and Durban, and the interaction between African and Indian Islamic groupings in KwaZulu-Natal more specifically. Mozambique and South Africa are in many respects very different societies, and have different modern political histories, with Mozambique winning independence from Portugal in 1974-5, and South African apartheid only coming to an end in 1994. At the same time, a historical comparison of state-civil society interactions in the two

Email: preben@ruc.dk 
countries appears meaningful, especially since 1994 when multi-partyism was introduced in Moçambique, and has not been attempted before. ${ }^{1}$

The article does not claim to be a systematic comparative analysis of state-civil society relations in the two countries since 1994, but offers an initial and tentative comparison. The special focus on the state side are the policies of secularism that have been pursued in Mozambique and South Africa, which both have strongly dominant ruling parties with a historical background in national liberation movements. On the civil society side, the article looks especially at Islamic organisations rooted in particular transnational Sufi brotherhood histories, and contrasts these with more scripturalist or 'fundamentalist' schools of Islam in Mozambique and South Africa, which have been inspired by wahaabism in the Arab world or by deobandism originating in India and Pakistan. The sources for the discussion have limitations, and are to a large extent drawn from the research undertaken, including personal communications and interviews conducted during periods of fieldwork in Northern Mozambique, Maputo, and KwaZulu-Natal.

The article compares forms of state in South Africa and Mozambique, which can both be characterised as dominant-party states operating within the frameworks of democratic multi-party constitutions. The dominant-party character of two states can be illustrated by the series of national assembly election results for the two countries since 1994 , when apartheid came to an end in South Africa, and multi-partyism was introduced in Mozambique (see details in Appendix 1).

As the figures in Appendix 1 indicate, developments in both Mozambique and South Africa initially moved steadily in the direction of an increase in the dominance of the dominant party. In Mozambique, this reached a climax in 2009, but was reversed in the 2014 elections, when the Resistência Nacional Moçambicana (RENAMO) made a comeback to challenge the dominance of the Frente de Libertação de Moçambique (FRELIMO). In South Africa, by contrast, dominance of the African National Congress (ANC) peaked in 2004, and has since been slowly decreasing with the Democratic Alliance emerging as the most significant opposition party. ${ }^{2}$

\footnotetext{
1 Thus Mozambique is not included in Roger Southall's recent comparison of Southern African state, see Southall, Liberation Movements in Power.

2 The Democratic Alliance has an electoral majority in the Western Cape Province. Minority parties like the Congress of the People (COPE) and Economic Freedom Fighters (EFF) may historically turn out to be temporary protest splinter parties from the ANC, rather than fully-
} 
Both South Africa and Mozambique are states that came into existence in the late $20^{\text {th }}$ century against a background of extended and violent liberation struggles, but there were a number of important differences in the ways the two liberation trajectories played themselves out, which can be outlined schematically as follows:

- While in South Africa, the armed struggle of the ANC/United Democratic Front (UDF) against apartheid went hand-in-hand with struggles through civil society to make the country ungovernable, the armed struggle in Mozambique of FRELIMO against the Portuguese colonial regime proceeded more through territorial conquest and the establishment of liberated zones

- While in South Africa, civil society mobilisations were expected to become foundations for alternative democratic institutions of government after liberation, expectations in Mozambique were rather for a revolutionary government to emerge directly out of the political structures created by armed liberation movement

In both South Africa and Mozambique, civil society was disempowered at the victory of the liberation movement, but in different ways:

- While in South Africa, the 'vibrant' civil society of the struggle against apartheid was initially side-lined and over-ruled by newly elected and ANC-dominated state institutions, the situation in Mozambique was rather that civil society was repressed as part of revolutionary transformation and in the context of the armed struggle against RENAMO

In a subsequent phase, then, side-lined or repressed civil society bodies and voices have been re-emerging to interact with the state in both South Africa and Mozambique, but again in different ways:

- In South Africa, new forms of post-liberation civil society have come to the fore to autonomously challenge the state and represent a democratic counterpoint to it. By

fledged alternative parties with a distinct agenda. The EFF, however, has established a spectacular left-populist presence, including the disruption of Parliamentary procedure by reduniformed EFF MPs. 
contrast, in Mozambique, repressed sections of civil society have been re-asserting themselves with different outcomes, with some of them being incorporated into the FRELIMO and the 'hegemonic bloc' supporting it, and others struggling to exist with a degree of autonomy, resisting the pressures for domination by political parties. ${ }^{3}$

These two contrasting trajectories could be discussed with reference to number of different social movement and civil society organisations, and have been researched and written about interestingly as far as traditional authorities are concerned. ${ }^{4}$ They are also important in the case of religious institutions like the Islamic movements and organisations, which provide the focus for discussion in this article, seeing them as important elements of civil society in the two contexts.

The mapping and analysing of the two trajectories of state-civil society engagement will tell us something about the strengths and weaknesses of the two varieties of a dominant-party state that have come to exist in South Africa and Mozambique respectively. This will apply in particular to the different approaches to secularism that have characterised the development of dominant-party government policy in the two countries since 1994, and which have provided alternative frameworks for the accommodation of Muslims as citizens and for the interaction with different varieties of Islam.

On the civil society side, the two trajectories provide an opportunity for discussing the role and impact of different types of Islamic practices and organisation as far as the development of a democratic public sphere and civil society dynamics are concerned. In particular, the article will look at the ways in which Sufi brotherhoods and Sufi-inspired Islam have provided an alternative to the more 'fundamentalist' forms of Islam that have been given more attention in recent discussions concerning Islam, politics and democracy in Africa. ${ }^{5}$

\section{Islam in Southern Africa: Elements of background}

\footnotetext{
3 Political society in the sense of Tocqueville, rather than of Partha Chatterjee. See Tocqueville, Democracy in America, 604-609; cf. Chatterjee, The Politics of the Governed, 38-41. See also Frederiksen, "Mungiki".

${ }^{4}$ See e.g. Buur and Kyed, "State Recognition"; Ntsebeza, "Traditional Authorities".

${ }^{5} \mathrm{Cf}$. Ahmed, Les conversions à l'Islam fondamentaliste, 33-97.; "Introduction" in Diouf, Tolerance, Democracy and Sufis, 1-35.
} 
What populations and types of Islamic practice are we talking about, when discussing Islam in Southern Africa and in South Africa and Mozambique more specifically? In terms of numbers, there is an important contrast between the two countries with Muslims making out about only 1.5\% or appr. one million people in South Africa and nearly $18 \%$ or appr. 3.6 million people in Mozambique. ${ }^{6}$ As argued by Abdou Malique Simone in a comparison of Islamic movements in Sudan and South Africa, the contrasting proportions may provide a different background for the ways in which Islamic voices join the public sphere, for political articulations of Islam, and for negotiations around secularism and a shared democratic framework for religious and cultural rights. ${ }^{7}$

The number of Muslims in South Africa is growing rapidly, however, and makes out a substantially greater proportion than $1.5 \%$ today due to the extensive immigration that has taken place since 1994 from countries with big Muslim populations like Senegal, Nigeria, Somalia, Malawi and, of course, Mozambique.

In Mozambique, the uneven distribution of the Muslim population is also significant with the great majority of it living in the poorest and most isolated parts of country to the north, where they represent the majority population in the Niassa, Cabo Delgado and Nampula provinces. Only a minority of Mozambican Muslims live in the south of the country, but important Islamic organisations have their bases in the capital Maputo, and the port of Maputo and its mosques has historically given the capital a special importance as a transit hub for both migration and religious transmission between the North and South of the country and internationally. The map in Appendix 2 gives an idea of the distribution of the Muslim population in Mozambique based on the 1997 census. $^{8}$

When it comes to the most important forms of Islamic practice in Southern Africa, three types have been particularly prominent. There is the Islam of the Cape of Good Hope as it was introduced along with the Dutch importation of slaves from the East Indies and Bengal from the seventeenth century, and subsequently also from the

\footnotetext{
6 Based on the South African census of 2001 and the Mozambican census of 2007. For Mozambique, cf. Cahen, Waniez and Brustlein, "Pour un atlas", 359; for South Africa cf. Vahed and Jeppie, "Multiple Communities".

7 Simone, "Advantageous Marginalities", 205-244.

8 The census, which indicated a dramatic rise in the overall size of the Muslim population in Mozambique, is discussed further in Cahen, Waniez and Brustlein, "Pour un Atlas", see especially 361-364.
} 
Mozambican Indian Ocean coast. ${ }^{9}$ Secondly there are the traditions of Indian Islam brought along by Gujarati traders, which came to be shared in South Africa also with indentured labourers from Bihar and Tamil Nadu from the late nineteenth century. ${ }^{10} \mathrm{In}$ Northern Mozambique, trading networks with Goa, Diu, and Daman have a much longer history, going back to the 17 th century, and have left their own marks on the development of Islam. ${ }^{11}$ New networks were added to these in the nineteenth century through the immigration of new Gujarati trading families with links also to Mauritius and to immigrants in East and South Africa. ${ }^{12}$ Finally, there are more indigenously African traditions of Islamic practice that have been stretching down the coast and been mediated by Swahili and other African trading networks, with strong representations into the nineteenth and twentieth centuries along the Northern Mozambique coast and its islands. ${ }^{13}$

The Indian Ocean has been a central arena for the unfolding of all these forms of religious practice and interaction, but in terms of research not enough has been made of how Indian Ocean dynamics and patterns of interaction reached into Southern Africa and affected its history and development. Relations between the East Indies and the Cape have been studied, and also relations of trade and migration across the Indian Ocean between India and South Africa and Mozambique. But along the African Indian Ocean coast a rupture of networks has been assumed to exist south of Beira-Sofala and reaching down to Durban and Natal - often explained with reference to the patterns and reach of effect of the monsoon winds. ${ }^{14}$ Myths of the mfecane and the impact of Zulu state building in the early nineteenth century have also played a part in explaining the idea of such a disconnection, though mfecane myth critics like Julian Cobbing and Norman Etherington have argued that the violence and upheavals of the region in the

\footnotetext{
9 Worden, Slavery in Dutch South Africa, 97-98; Datta, From Bengal to the Cape, 67-69; Tayob, Islam in South Africa, 34-40; Worden, "Indian Ocean Slaves in Cape Town".

10 Vahed, "Constructions of Community"; Desai and Vahed, Inside Indenture, 214-227; Green, Bombay Islam, 208-234.

11 The crucial role of both Hindu and Muslim Indian traders in underwriting the slave trade from Mozambique is discussed in Capela, $O$ Tráfico de Escravos, 63-66, and more extensively in Machado, Ocean of Trade, 208-267.

12 Pereira Bastos, "Indian Transnationalisms"; Khouri and Pereira Leite, "Indians of Eastern Africa".

13 Bonate, "Traditions and Transition"; Kaarsholm, "Transnational Islam"; Bang, Islamic Sufi Networks, 90-107

${ }^{14}$ See e.g. Pearson, The Indian Ocean, 19-24.
} 
early nineteenth century were caused to a significant extent by the displacements of the Portuguese Indian Ocean slave trade. ${ }^{15}$

\section{Islamic connections between South Africa and Mozambique}

My recent research has aimed at by-passing this assumed rupture and has studied Islamic movements and forms of interaction between South Africa - most importantly what is now KwaZulu-Natal, but involving also the Cape - and Mozambique. These include Indian Islamic networks - stretching between South Asia and South Africa and South Asia and Mozambique, but also involving - though to a surprisingly limited extent - linkages between Indian Muslims in South Africa and Mozambique. Only limited research has been done on the new linkages between traders in Northern Mozambique and India that came about from the late nineteenth century, and even less on the relations between Indian families of traders in Northern Mozambique and in Natal. These families travelled and arrived in Africa at around the same time, but their paths divided as they entered different linguistic worlds, and to different degrees lost touch with their Indian homelands. ${ }^{16}$

As far as Indian Islam is concerned, such networks have been predominantly sunni with a background in mostly the hanafi school of Islamic law, and have included very different positions and outlooks, from more open-minded barelwi and Sufi varieties to more scripturalist deobandi and tablighi jama'at-oriented ones. In Durban this has involved occasional clashes - as in the 1970s - between them around the appropriateness of the visitation of graves, healing, the organisation of muharram processions, the authority of pirs, mawlid celebrations, and ritual practices like urs ('wedding', death anniversary of saint). ${ }^{17}$ With exceptions like the one discussed below, Indian Sufism in South Africa has usually been quite distinct from African Sufi Islam. ${ }^{18}$

In Northern Mozambique (Nampula, Nacala, Ilha de Moçambique), proclaimed Indian sunni organisations like CIMO - the Comunidade Islamica de Moçambique - have

\footnotetext{
15 Cobbing, "The Mfecane as Alibi"; Etherington, The Great Treks, 147-182. This revisionism has recently been challenged back in Jeff Guy, Theophilus Shepstone, 79-81. On the displacements caused by the slave trade in Mozambique, see also Capela, 0 Tráfico, 273-303.

${ }^{16}$ New research by Goolam Vahed on traders like Moosa Hajee Cassim promises to make amends for this, see Vahed, "Family, Gender, and Mobility".

17 Vahed, "Contesting Orthodoxy".

18 Cf. Green, Bombay Islam, 228; Kaarsholm "Transnational Islam".
} 
been important and financially resourceful bases of support for the African Sufi orders. This has been important for their success in standing against the inroads made by wahaabi and other 'purifying' and anti-traditionalist Islamic reform movements since the late 1990 s. $^{19}$

Islamic networks thus also include African ones that have followed their own trajectories and dynamics even if they have interacted with Indian networks and those of what in Mozambique are called 'Moors' - referring literally to Arabs or Arab-speakers, but often in Portuguese usage implying mixed-race or Indian Muslims claiming Arab descent. $^{20}$ Since 1994, such African networks in both South Africa and Mozambique have been powerfully re-inforced by immigration following the end of apartheid influx control in South Africa, and stimulated by both opportunity migration and the displacements caused by violent conflict and political meltdown in other African countries. ${ }^{21}$ While some research has been done on Somali networks in South Africa, work on immigration networks in Mozambique and down the Indian Ocean coastline is still in short supply. ${ }^{22}$

Like in earlier decades, African Islamic immigrants have been able to relate to older networks as represented by the Makua diasporas created by the eighteenth- and nineteenth-century Indian Ocean slave trade in e.g. Madagascar, Mauritius, the Seychelles, Somalia (Jubaland on the Kenyan border), in India, and in South Africa. ${ }^{23}$ It is remarkable that - in spite of intense interest and monitoring - there has been very little solid by way of reporting a presence of East African violent Islamic movements in

\footnotetext{
${ }^{19}$ Bonate, "Islam in Northern Mozambique"; Declich, "Transmission of Muslim Practices". CIMO follows on the earlier Comunidade Mahometana de Moçambique (CMM), and has been important for the affiliation of Indian Muslims to the national Islamic Congress of Mozambique. As discussed further below, Shia Ismaili Islam has also been significant historically in Mozambique, see Pereira Leite and Khouri, "História Social e Económica dos Ismailis" and Khouri and Pereira Leite, eds. Khojas Ismaïli.
}

${ }^{20}$ Bonate explains 'Moor' as "a Portuguese term applied to Muslims in general, and to Indians or those descending from Muslim Indians and local African women in particular, whom the Portuguese also often identified as the descendants of the 'Moors of Daman' (Mouros de Damão ) in Gujarat, India". See Bonate, "Traditions and Transitions", 73, note 277. Cf. Machado, Ocean of Trade, 268f., on the links between Muslim Khoja and Ismaili merchants, Muscat, Zanzibar and the Omani commercial empire.

${ }^{21}$ Landau, "African Urbanization".

22 Sadouni, "Somalis in Johannesburg" and "Playing Global".

23 On the slave trade and the dispersion of Makuas, see Allen, "The Constant Demand"; on Makua diasporas in Somalia and Madagascar, see Declich, "'Gendered Narratives'" and Boyer-Rossol, "De Morima à Morondava". 
Mozambique or South Africa. There have been concerns about the porosity of the North Mozambican border and the Querimbas coastline, and after the Nairobi Westgate attack in September 2013 rumours went around that the 'White widow' of one the July 2007 London Underground bombers, Samantha Lethwaite, had been involved, going in and out on a South African passport. But the rumours have remained unverified, and AlShabaab itself declared that no women could have been involved. ${ }^{24}$ Mozambican research on the increase of immigration into Northern Mozambique along the coast has highlighted the high number of illegal immigrants, who are reluctant to disclose their origins, but many of whom are likely to be Somalis. ${ }^{25}$

The African Islamic networks I have studied most particularly in South Africa have been small and peaceful ones, centering on a Makua-speaking community in Durban, known as 'Zanzibaris'. The community originated in a group of 509 liberated slaves, whom the British Navy liberated from dhows intercepted off the coast of Northern Mozambique near Ilha de Moçambique and Angoche. In Durban they were placed under contract for five years as indentured labourers alongside Indian sugar workers, arriving in different batches between 1873 and 1875, and my research has explored their uses of Islam to build community and manoeuvre politically. From the early $20^{\text {th }}$ century groups likes the Zanzibaris became bridgeheads in South Africa for African Sufi networks and brotherhoods like the Rifaiyya, the Shadhiliyya and the Qadiriyya and thus represented advance positions for the expansion of very specific forms of Islamic practice and networking. ${ }^{26}$

'Brotherhood' is a misleading denomination for the Rifaiyya, Shadhiliyya and Qadiriyya Sufi orders since they have given space to women and include women khalifas in their hierarchies. In South Africa and Durban, the African Sufis interacted with, but mostly stayed separate from similar orders arriving ifrom India and Bombay, and developed links to the Cape where Sufi orders with the same names had already established a presence through a trajectory from Dutch East India. But the most direct

\footnotetext{
24 On the 'White widow' rumours, see Wikipedia http://en.wikipedia.org/wiki/Samantha_Lewthwaite (accessed 2 December 2014). The rumours were recycled in the British press without further documentation after the Al-Shabaab Garissa attack in April 2015.

25 The biggest group of coastal immigrants in Northern Mozambique, though, come from Tanzania. See Araujo and Donado, "Communidades Costeiras", 4-6. Cf. Borges Coelho, "Uneasy Shores". 26 Kaarsholm, "Zanzibaris or Amakhuwa".
} 
linkages for African Sufism in Durban reach towards the north to Maputo and from Maputo further north to Angoche and Ilha de Moçambique - the great centre for Islamic Sufi brotherhoods. In Ilha, they connect with Palma, the Comoros and Zanzibar, Lamu, Brava, and the Arab world, as part of African coastal and Swahili networks that are better known, but which have only been studied to a limited degree at this southern latitude. ${ }^{27}$ Against this background and making use of such linkages, the Makuaspeaking freed slaves of Durban were able to re-invent themselves as Zanzibaris or 'Swahilis'. In this, they followed a pattern of 'Swahilisation' that is well-known elsewhere along the coast, but unique inasmuch as the Durban Zanzibaris held on to their Makua language - stigmatized elsewhere as a language of slaves. It is this combination of Sufi Islam and the Makua language as markers of community identity, which made it possible for the Zanzibaris subsequently to re-assert themselves after the end of apartheid as Amakhuwa and as Africans with a dual national belonging in both South Africa and Mozambique. ${ }^{28}$

\section{The usefulness of Makua and Sufi Islamic networks}

These late 19th and 20th century networks served predominantly to facilitate trade, migration, education and religious and cultural interaction - providing the machinery of exchange within what Nile Green has called a 'religious economy' or an 'economy of enchantment'. ${ }^{29}$ But perhaps most importantly their function was to establish a degree of transnational autonomy and freedom of movement vis-à-vis state regulation. This was demonstrated by the success of invented identities like that of Zanzibaris, but also in the achievements of evading and circumventing systems of population movement control during the period of apartheid influx control in South Africa as well as colonial restrictions on movement in Mozambique. The Zanzibari settlement on the Bluff in Durban thus became a popular entry point for Muslim migrants from Mozambique and Malawi in particular, looking for job opportunities or seeking an escape from persecution

At the same time, the Mozambique connection supplied the Zanzibaris with important linkages of education and support as well as cultural resources, e. g. in the

\footnotetext{
27 Bonate, "Traditions and Transition", 30-72; Bang, Islamic Sufi Networks, 22-46.

28 Kaarsholm, "Diasporas or Transnational Citizens?".

${ }^{29}$ Green, Bombay Islam, 18.
} 
field of cultural expertise and healing, basing themselves on Mozambican cultural resources. These included both herbal and Islamic medicines and hiriz - short texts from the Qur'an that can be dissolved and swallowed with an effect of healing. Hiriz has also been used to fortify the body before undergoing the piercing rituals of ratiep that are sometimes part of Sufi celebrations of mawlid, the Prophet's birthday, in both Mozambqiue and South Africa. They also included the daira and duffu drums used in mawlid celebrations. ${ }^{30}$

Ritual and ritual expertise and power were thus prominent in transmissions, and provided a link between the Durban Zanzibaris and not only Northern Mozambique, but also in fact Zanzibar, which together with the Comoros islands, were central nodes in the networks through which the Rifaiyya, Qadiriyya and Shadhiliyya Sufi networks expanded towards Mozambique and South Africa from the end of the nineteenth century. ${ }^{31}$ In this way South African ratiep - which has been studied more as 'fakir dancing' or 'khalifa' in Cape Town, where it had arrived first through older versions of Sufi networks from Dutch East Asia - in Durban continued and re-invented Islamic brotherhood rituals like the mawlid nakira, the mawlid yahum, the mawlid al habshi known from Zanzibar and Lamu. A characteristic of this is the chanting and sitting-down dancing of male groups, performing dhikr, which in Mozambique became a famous instance of folk culture in the more modern version by female cultural groups known as tufo and secularised under early FRELIMO governance. ${ }^{32}$

The port city of Maputo - the former Lourenço Marques - has been an important hub inbetween South Africa and the Sufi centres in Ilha and Northern Mozambique, and on the Durban Bluff, the Zanzibaris lived just above the harbour, where many of them worked. They were great fisheaters and seafarers, and many Zanzibari/Makua culinary and cultural specialities are linked to the sea and sea travel. Muslim sailors from Mozambique would make their way to the Bluff, and as dockers, ship repair workers, and Zanzibaris would visit Maputo, and move in and out of the city both in colonial times, during apartheid and after. In Maputo, the Qadiriyya and Shadhiliyya mosques in the Makua-speaking townships of Mafalala and Minkajuine have been especially central

\footnotetext{
30 Interviews with members of the Amakhuwa Research Committee, Bayview, Durban, January 2014. An extended account can be found in Kaarsholm, "Zanzibaris or Amakhuwa?".

31 See also Pouwels, Horn and Crescent, 191-208; Bang, Sufis and Scholars of the Sea, 126-152.

32 Nuotio, "The Dance that is not Danced"; Arnfred, "Tufo Dancing".
} 
to Sufi network exchanges, and extended Durban-Mozambican family networks have been influential within them, and continue to control the Shadhiliyya mosque. ${ }^{33}$

Some network activities - both political, economic and cultural - are not so easy to get to know about, but some are known thanks to the monitoring of the state. This applies e.g. to the travels of the famous Ilha de Moçambique Qadiriyya shehe, Sayyid ba Hasan, who travelled extensively and also covered the trail between Ilha and Durban, where he established a family. We know about this from the research of Liazzat Bonate into the surveillance records of the Portuguese colonial authorities, who monitored his movements and tried to understand his networks. ${ }^{34}$ Sayyid ba Hasan died and was buried in the central Islamic cemetery in Maputo in 1963 - his grave there is still visited by people who believe in its healing and miracle-working capacities, and who sing songs about the good deeds of ba Hasan. When I visited the grave in January 2014 together with ba Hasan's great-grandson, Said Habib - an imam at the Polana mosque in central Maputo and an advisor to the Mozambican President on Islamic affairs, trained in at the All Africa University in Khartoum - he carefully cleaned the grave of the grass which had overgrown it and of coins that had been left on it, giving a practical demonstration of the shift from traditionalist Sufism to modernist reformism. ${ }^{35}$

\section{Islam and state-civil society interaction in South Africa and Mozambique}

If we try to compare the inclusion of Islamic groupings in South Africa and Mozambique in state-civil society interaction, this - in South Africa after 1994 - has been extensive. This may have to do with the small minority status of the Muslim population as argued by Simone (see above), but it has other reasons as well. One is the the post-apartheid South African Constitution, which includes a comprehensive Bill of Rights, incorporating cultural rights, which - as supervised by the South African Constitutional Court - has offered a framework for the negotiation of multiculturalism, and has to some degree

\footnotetext{
33 Interviews with mosque officials, Maputo, January 2014, and with members of the Amakhuwa Research Committee, Bayview, Durban, January 2014.

34 Surveilance records and government reports are discussed in Bonate, "Traditions and Transitions", 13, 127-135.

35 Interview with Said Habib, Maputo, 22 January 2014; on the songs commemorating Sayyid ba Hasan's miracle working, interview with Shehe Omar Bishehe Abdallah, Nampula, 27 January 2011.
} 
made sense of the slogan of the 'Rainbow Nation'. ${ }^{36}$ Another reason lies with the diversity of the South African Muslim population, which has given rise to a public space for debate between groups, views and positions. ${ }^{37}$ Further, the African National Congress has had prominent Muslims among its elite members, and influential ANC ministers like Kader Asmal and the late Dullah Omar have been Muslims. As Minister of Transport, Omar was responsible for the opening of the new cross-border coastal road connecting Durban with Maputo through Kosi Bay and Ponta Douro, which - besides furthering tourism - was a gesture towards the accelerated unfolding of networks.

Diversity and inclusiveness have their historical roots in the different trajectories through which South African Muslim communities have developed - with very different characteristics and periodization in e.g. the Cape and Natal - and in the ways in different groups of Muslims related to apartheid and to the anti-apartheid liberations struggle. Some Muslim groups were politically quietist, or collaborated with apartheid multiculturalism through the Tricameral Parliament - including some of the more conservative groups of Indian Muslims in Natal, often linked since the 1960s to Tabligh Jamaat reformationism.

On the other hand, from the 1970s, youth-based organisations like the Muslim Youth Movement (MYM), Qiblah and the Call of Islam (CoI), which centered on the Cape, but also had support in Natal and on the Rand, would be much more politically inspired, and would link up with radical left movements in different ways. While MYM was important in supporting the recruitment of Black Africans and in confronting the authority of conservative imams, Qiblah and the CoI developed more outward-looking links with nationalist liberation movements - Qiblah with the Pan-African Congress (PAC), the CoI with the UDF, which in the 1980s came to stand in for the illegal ANC. ${ }^{38}$ This contributed to both diversity and liberation struggle respectability and credentials, which were important for post-apartheid recognition and inclusion. It also helped to make it possible to defuse the challenge from the violent, Muslim-based PAGAD movement - People Against Gangsterism and Drugs - which emerged in the Cape as an

\footnotetext{
${ }^{36}$ In its inclusiveness the South African constitution is comparable to the Canadian constitution, and - as a more recent example for discussion - the Kenyan constitution of 2013. Inclusiveness of rights can of course present problems of contradiction as well as possibilities for compromise and mediation as will be discussed further below.

37 Vahed and Jeppie, "Multiple Communities"; Tayob, "Muslim Publics".

38 Tayob, Islamic Resurgence, 148-156.
} 
anti-state moralist vigilante movement in the mid-1990s, but never came to represent a South African 'terrorist threat'. 39

Another example of interaction is the discussion around Muslim Personal Law, where the South African Constitution has provided a workable framework for consultations. This has resulted in practical propositions for ways in which the different sets of entitlements within the Bill of Right can be reconciled, and working out possibilities for recognising Muslim cultural and religious rights through legislation on inheritance, marriage and women's rights, while respecting also other fundamental Constitutional rights. The codification of the revised framework for Muslim Personal Law has so far, however, been blocked by opposition from conservative groupings. Their counter-argument is the paradoxical one that the South African Constitution is in itself unconstitutional, since it does not recognize that different cultural communities - like Muslims - must each be allowed to set their own legal frameworks, rules and institutions. ${ }^{40}$

In general terms, Islam in South Africa after 1994 has been able to establish both its own frameworks of an Islamic public sphere, and at the same time to find accommodation within the setting of a more comprehensive national public space, whose moderate, compromise-oriented secularism has allowed Muslims and Islamic organizations to be important parts of post-apartheid South African civil society. This again has allowed Islamic organisations to be prominent in the reception of immigrants, and in the reconciliation of conflict and violence relating to xenophobia. Mosques in central Durban, for example, have been important centres and rallying points for both West African Muslim immigrants, and for the Somali traders who have helped to resurrect the ailing businesses of Durban's traditional central business district. ${ }^{41}$

Diversity has also meant that - with Durban as a good example - South Africa has provided an arena for energetic debate between different Islamic views and those of the Christian evangelical and Pentecostal groupings that have also been gaining ground. For a long time Ahmed Deedat's Islamic Propagation Centre International (IPCI) was at the centre of this. ${ }^{42}$

\footnotetext{
39 Vahed, "Islam in the Public Sphere of South Africa".

40 Moosa, "Muslim Family Law in South Africa", 342.

41 Misgun, "Foreign Migrants".

42 Vahed, Ahmed Deedat, 81-90.
} 
In the context of my own recent research, an example of post-1994 state recognition of Muslim citizens' claims is the land restitution case, which in 2004 gave the Zanzibari community the land back at Kings Rest in Durban from which they were forcefully removed under the Group Areas Act in 1962. The implementation of land restitution is still on-going and involves complicated issues around the delimitation of community membership, different interests concerning restitution (as land or cash compensation), and violent protests from the white residents on the Bluff against being joined by new Black African neighbours. It also involves interesting debates concerning how exactly a historical situation that was discontinued more than fifty years ago can be brought back to life. This is of course not physically or literally possible, but calls for a representation of the history of Islam and migration in Durban which involves heated and complicated debates around the rights to represent, as has been the case also around Muslim history in Cape Town, and the District Six, Bo-Kaap, and Simonstown commemoration projects. ${ }^{43}$

Such debates and a competing - and lost - land claim by the resourceful Durban Juma Masjid Trust have led to a rift in old alliances between African Sufis and Indian Sunnis - exactly the kind of alliances which have also helped to sustain the African Sufi orders in Northern Mozambique. When I visited Bayview in October 2014, builders commissioned by the Juma Masjid Trust, who are the owners of the land, on which the Rahmaniya Mosque is situated, were busy fencing in the land to protect the property against squatters. Meanwhile, Zanzibaris have intensified their links with Mozambique and their orientation towards Makua language and cultural rights. After a period of relative decline, ratiep performances and celebrations of mawlid have been brought back to life with extensive backing, as exemplified by the three-day mawlid celebrations that was held in Bayview in April 2013.

As far as state-civil society relations are concerned, Mozambique has been going through a different history. Important in this history has been the continued marginalisation of Northern Mozambique, which goes back to the fragility of Portuguese colonial rule, which did not establish an effective presence in the Islamic North until the 1920s. ${ }^{44}$ This gave extensive power to sub-state institutions like chiefs and shehes and alliances between them - developments which left an important imprint on the

\footnotetext{
${ }^{43}$ Kaarsholm, "Zanzibaris or Amakhuwa?".

${ }^{44}$ Newitt, A History of Mozambique, 398-401. Cf. Hafkin, "Trade, Society, and Politics", 359ff.
} 
character of the Sufi networks that have been the most important Islamic institutions in the North. ${ }^{45}$ In this field again, the research of Liazzat Bonate has been path-breaking. By contrast to these more indigenous authorities, Portuguese rule was based on Christianity as the basis for citizenship and inclusion and on radical measures of segregation - not so much between races, as between those were 'Portugalised', 'civilisado' or 'nao-indigena', and those who belonged to the 'indigenato'.46

Only very belatedly in the years before Independence did the Portuguese try to ally themselves with Muslims in the North - considered at this late stage to represent a benevolent form of 'islão negro' as against the radicalism of wahaabis - but without much success: Muslims of the North would rather support the nationalist movements and guerrillas crossing in from Tanzania. ${ }^{47}$ Nonetheless, suspicions of collaboration came to be used as legitimation for the suppression of Muslim culture and authorities, which went along with FRELIMO's policy of radical secularism and 'anti-obscurantism' that was adopted in 1977.48 Though this policy of 'hard' secularism was softened somewhat from the 1980s, it remained a framework of constitutional rights, outlook and policy that was very different from the South African situation and made for very different dynamics of interaction between the state and civil society. On the civil society side, Joana Pereira Leite has highlighted the dramatic group exodus from Mozambique between 1973 and 1976 of Shia Ismaili Muslims in the context of the war of liberation, independence, and following the Ugandan expulsion of Indians of 1972.49

At the same time, post-colonial FRELIMO government continued the traditions of fragility, neglect and underdevelopment established by colonialism in the North, and this weakness of the state together with its anti-Islamic policies led parts of the North to support RENAMO in the civil war that raged between the early 1980s and 1992. In this context, the dominant party revised its policies and encouraged the formation of Islamic associations that could be negotiated with, like CISLAMO - the Islamic Council of

\footnotetext{
45 Bonate, "Islam in Northern Mozambique".

46 Newitt, A History of Mozambique, 441f. Cf. Cabrita, Mozambique: The Tortuous Road, 120-123.

47 Bonate, "Muslims of Northern Mozambique". Cf. Alpers, "Islam in the Service of Colonialism?".

48 Bonate, "Muslim Religious Leadership", 643.

${ }^{49}$ Pereira Leite, Khouri and Mascarenhas, "Les departs des Ismailis." Cf. Melo, "A Diáspora Ismaelita".
} 
Mozambique, formed in 1981 - and the Islamic Congress of Mozambique, formed in 1983.50

CISLAMO was dominated by tablighis and deobandi groups and what was according to Bonate - originally radically uncompromising groups of wahaabis, led by Aboobacar Mangira and linked to the Arab world through well-resourced Islamic NGOs like the Africa Muslim Agency. ${ }^{51}$ By contrast, the Congress had its power base in the North and among the Sufi orders. This led to heated and sometimes violent confrontations, especially as FRELIMO initially favoured CISLAMO with its base in the South and Maputo and - not least - because of the diplomatic and business connections that could be pursued with Arab countries and the Middle East through CISLAMO. Later - especially since the appointment of the Aminuddin Muhammad - the Director of the Muslim Hamza College in Matola - as National Secretary of CISLAMO, the opposition would become framed in less antagonistic terms, with Sufi reformers like Said Habib mentioned above joining in to the debate as to whether the Qadiriyya and Shadhiliyya orders are 'traditionalist' and 'outdated'.52

From 1994, however, when multi-partyism was introduced, FRELIMO changed its policy again, and tried to win support in the North against the power of RENAMO through collaboration with Sufi leaders of Northern Mozambique. This included alliances with the leader of the Qadiriyya Bagdade in Ilha de Mocambique, shehe Abdulrazaq Jamu, as well as with the leader of the Shadhiliyya Yashrutiyya in Ilha, shehe Sayyid Amurri bin Gimba. Another prominent Northerner, Dr Jose Ibraimo a lawyer from Angoche with strong links to the Shadhiliyya, was included in the FRELIMO government between 1994 and 2004 as Minister of Justice. ${ }^{53}$

FRELIMO has been sceptical, however, concerning this alliance, and has suspected Muslims of following their own anti-secularist agendas, and supporting RENAMO. There has not been any compromise agreement around Muslim Personal or Family Law as such, and the Constitution of 1990 and later amendments in 1996, 1998

\footnotetext{
50 Morier-Genoud, "Muslims and Political Power"; Bonate, "Muslim Religious Leadership", 2008; Bonate, "Islam in Northern Mozambique".

${ }^{51}$ An interesting alternative wahaabi perspective is provided in Kadara Swaleh's article on his father's missionising in Mozambique. See Swaleh, "Islamic Proselytising", 414-418.

52 Interview with Aminuddin Mohammad, Matola, 8 February 2011; interview with Said Habib, Maputo, 22 January 2014.

53 Morier-Genoud, "Muslims and Political Power in Mozambique"; interviews with Jose Abudo, Maputo, 7 February 2011 and 21 January 2014.
} 
and 2004 - though allowing space for decentralisation and some recognition of traditional institutions - does not provide a framework for the negotiation and regulation of cultural and religious rights. The Family Law Act of 2004, which applies to all groups of citizens, outlaws polygamy, but does not provide rules or institution to enforce or negotiate this, while - contradictorily - inheritance laws have been passed that entitle all wives of a husband to inherit equally. ${ }^{4}$

FRELIMO's romance with the Sufi orders in the North faded out after 2004, when the dominant party finally succeeded in winning a majority also in this part of the country, and the Muslim ministers, including Abudo, were not re-appointed, though FRELIMO continued a policy of collaboration with 'secular Muslims'. ${ }^{55}$ In consequence of this, Northern Muslims made a turn towards civil society, creating educational foundations and re-inventing brotherhood structures as community development organisations. A new generation of Qadiriyya and Shadhiliyya leaders - like Hafiz Jamu, the son of Abdulrazzaque Jamu, of the Qadiriyya Bagdade, and Saide bin Gimba Amur, the son of Saide Amurri bin Gimba of the Shadhiliyya Yashrutiyya - enlisted for development studies training at the Catholic University of Mozambique campus in Nampula, and put this to practical use in various projects in Ilha de Moçambique and Nampula Province. As we saw, a third member of the same generation - Said Habib, the great-grandson of Sayyid ba Hasan and the son of the leader of the Qadiriyya Sadat, shehe Sayyid Habib Bakr - went to the All Africa University in Sudan instead, and returned - not to the North, but to Maputo - a modernist reformer. ${ }^{56}$

In the most recent period, Sufi Islam in the South, including Maputo, seems to have been on the defensive vis-à-vis the reformist and wahaabi impact, with declining support for the central Shadhiliyya and Qadiriyya mosques in Mafalala, but the contestation is still undecided, and Durban Sufis have attempted to bring in support. There may have been a decline in mawlid celebrations in Southern Mozambique, though in 2008, Jose Abudo of the Islamic Congress of Mozambique and Margarita Talapa of the Mozambican Muslim Women's Association took the lead in organising a huge ziyara festival in Maputo. This became a rally not only of Sufi order members, but also of

\footnotetext{
${ }^{54}$ Buur and Kyed, "State Recognition"; CEDAW, "Shadow Report".

55 Morier-Genoud, "Muslims and Political Power", 264f.

56 On Abdulrazzaque Jamu, Sayyid Amurri bin Gimba, Sayyid Habib Bakr and the leadership of the major Qadiriyya and Shadhiliyya groupings from the 1960s after the death of Sayyid ba Hasan, see Bonate, "Traditions and Transitions", 102-107.
} 
Makua speakers from many parts, including Durban, and a manifestation of strength on behalf of Northern Mozambique which was attended by President Guebuza.

At the same time, celebrations of mawlid in the North appear to have been increasing and finding growing support in both Ilha, Nampula, Nacala and Angoche. On 19 January 2014, I attended the mawlid celebrations in Ilha de Moçambique organised by the Sufi orders with the financial and logistical support of CIMO - the Sunni Comunidade Islamica de Moçambique. This was a major display of strength and of reclaiming public space, starting with a march around the perimeters of the whole island from the early morning.

It was also the occasion for celebrating the victory in the municipal elections in Ilha de Moçambique in November 2013 of the young Shadhiliyya shehe Saide bin Gimba Amur as mayor of Ilha, and in his speech at the mawlid the mayor acknowledged that his victory was due to the strength of the Sufi orders of people's respect for them. The victory seems to have been the outcome of something of a local youth rebellion within FRELIMO as well as of lack of respect for the opposing Movimento Democrático de Moçambique (MDM) candidate (as was noted above RENAMO boycotted the municipal elections). ${ }^{57}$

In the 15 October 2014 Presidential and National Assembly elections, RENAMO did contest and made a remarkable comeback, with Afonso Dhlakama winning 36.61 \% of votes in the Presidential election against Filipe Nyusi's $57.03 \%$, and taking $32.46 \%$ of the votes in the National Assembly elections against FRELIMO's 55.93 and MDM's 8,35 $\% .^{58}$ The October 2014 elections thus reduced the majority of the dominant FRELIMO party significantly. This trend was clearly expressed in the National Assembly voting in Nampula Province also, where RENAMO and FRELIMO each won 22 seats and MDM three seats. In the elections for Provincial Assembly seats in Nampula, there were variations, however, with an overall result of FRELIMO taking 47 seats against RENAMO's 45 and only one for MDM. In Nampula City, RENAMO won the elections, taking seven seats against FRELIMO's five and MDM's one. In Ilha de Moçambique,

\footnotetext{
57 In the municipal elections held in November 2013 (and boycotted by RENAMO), FRELIMO won 50 out of 53 municipalities, but the opposition party MDM won in Nampula, Quelimane and Beira, and on a national scale won $30 \%$ of the number of municipal assembly seats. See Mozambique Political Process Bulletin, no. 54, part one, 23 December 2013: 1.

58 For the Presidential election results, see 2014 National Elections: Mozambique Political Process Bulletin, No. NE-74, 30 October 2014. For the National Assembly results, see Appendix 1 below.
} 
however - where the Shadhiliyya shehe Saide Amur had been elected Mayor in November 2013 - FRELIMO won the seat, running against the general trend. 59

The renewed alliance between FRELIMO and the local Sufi leadership in Ilha therefore appeared to have paid off. Meanwhile at the national level, FRELIMO for the elections had consolidated their links with CISLAMO - the Islamic Council of Mozambique - and the anti-Sufi reformationists based in the South of the country, by having the General Secretary of CISLAMO, Abdul Carimo, appointed Chairman of the National Elections Commission (CNE). ${ }^{60}$ This helped to drive a wedge between RENAMO and some potential Muslim supporters, and became significant later as the CNE rejected RENAMO complaints over election irregularities, making Afonso Dhlakama refer to its Chairman, Abdul Carimo, contemptuously as 'the Muslim'.61

In this way, the battle for state control of the North of Mozambique remained of central importance, as did the battle for the Muslim vote - and for the incorporation of the different Muslim constituencies of Mozambique into a political society dominated by either FRELIMO or RENAMO.

\section{Conclusion}

What the above discussion has demonstrated, I hope, is that in a comparison between the two dominant-party regimes of South Africa and Mozambique, South Africa comes out as the stronger alternative because of its different framework and modus for interaction with civil society, as exemplified by Islamic groupings and institutions. This may qualify some of the reservations that have recently been directed at the South African state for suppressing or even violently attacking its civil society counterparts. Instances of this have included the Marikana shootings of trade union activists, violent interventions against service delivery protests or the uprisings of slum dwellers, but also interferences with media to limit reports on self-serving representatives of the 'party state' that has grown out of the ANC as a liberation movement.62 In spite of

\footnotetext{
${ }_{59}$ Mozambique Political Process Bulletin, No. 56, 28 November 2014, 14 and 16. 60 "Mozambique: Abdul Carimo Appointed CNE Chairperson", All Africa, 27 May 2013 http://allafrica.com/stories/201305280275.html (accessed on 1 December 2014). 612014 National Elections: Mozambique Political Process Bulletin, No. NE-76, 9 November 2014, 2.

62 Southall, Liberation Movements. On Marikana, see Kaarsholm, "Africa Globalized?"; Breckenridge, "Marikana and the Limits of Biopolitics".
} 
confrontations and mal-functions, a framework and sets of regulation have been evolving that protects the autonomy of civil society vis-à-vis the state. Together with the gradual decrease in the dominance of the dominant party, this has served to strengthen and stabilise the South African post-apartheid state rather than weaken it.

In Mozambique, by contrast, the multipartyist, post-1994 state has continued to be weak - partly because of its lack of outreach and of recognition of its legitimacy in the North of the country. If we use the state's interaction with Islamic institutions after 1994 as example, relations between state and civil society have been characterised by invasion, co-optation, or marginalisation rather than by dialogue, and the development of a stable democratic framework and sets of rules. This has weakened the dominantparty state, and has helped bring about a situation where - with the decline in FRELIMO dominance - the alternative seems to the emergence of another dominant party, maybe even backed by armed and violent mobilisation. Instead of signalling an outlook of peace and pluralism, the challenge represented by RENAMO to FRELIMO in the North appears to threaten renewed civil war and destabilisation. The absence of a consolidation of democracy is indicated by the overruling of civil society by political society, and the turning into political pawns of civil society institutions like the Islamic movements and organisations.

In the face of this, the Sufi networks and the transnational linkages discussed between Makua speakers in South Africa and Mozambique may be seen to point to new opportunities for civil society organisation that present an alternative both to nationalist mobilisations with a fixed focus on the state, and to multinational enterprises of ideology and culture imposed from above. Rather than being outmoded and traditionalist, such networks of multiple belonging and mediated through language and Islamic ritual may present a way forward to movements of everyday globalisation from below, through which both new notions of citizenships and transnational democratic potentials may be developed.

\section{Acknowledgements}

This paper was developed through discussions at two international workshops held at Roskilde University in November 2013 and May 2014, and owes a lot to the constructive comments received from workshop participants and discussants. The two workshops 
were organised jointly by the AEGIS collaborative research group on 'Africa in the Indian Ocean' and the Roskilde University research priority initiative on 'The Dynamics of Globalisation, Inequality and New Processes of International Interaction'. The funding provided by Roskilde University for the workshops is gratefully acknowledged. The comments from the two anonymous reviewers were helpful and much appreciated.

\section{Notes}

$<$ footnotes to be converted to endnotes and inserted here $>$

\section{Bibliography}

Ahmed, Chanfi. Les conversions à l'islam fondamentaliste: le cas de la Tanzanie et du Kenya. Paris: L'Harmattan, 2008.

Allen, Richard. "The Constant Demand of the French: The Mascarene Slave Trade and the Worlds of the Indian Ocean and Atlantic during the Eighteenth and Nineteenth Centuries." Journal of African History, 49, 2008: 43-72.

Alpers, Edward A. "Islam in the Servide of Colonialism? Portuguese Strategy during the Armed Liberation Struggle in Mozambique." Lusotopie, 1999: 165-184.

Araujo, Manuel G. M. de and João Donato. "Comunidades Costeiras em Moçambique." CESAB Documento de Trabalho. Maputo: Centro de Estudos Sociais Aquino de Bragança, n.d.

Arnfred, Signe, "Tufo dancing: Muslim women's culture in northern Mozambique", [1999], in Signe Arnfred (ed.), Sexuality and Gender Politics in Mozambique: Rethinking Gender in Africa, 265-290. Woodbridge: James Currey, 2011.

Bang, Anne K. Sufis and Scholars of the Sea: Family Networks in East Africa, 1860-1925. Abingdon: Routledge-Curzon, 2003. 
Bang, Anne K. Islamic Sufi Networks in the Western Indian Ocean (c. 1880-1940: Ripples of Reform: Islamic Reform in the Southwestern Indian Ocean, c. 1860-1930. Leiden: Brill, 2014.

Bonate, Liazzat. "Traditions and Transitions: Islam and Chiefship in Northern Mozambique, ca. 1850-1974." PhD diss., University of Cape Town, 2007.

Bonate, Liazzat. "Muslim Religious Leadership in Post-Colonial Mozambique." South African Historical Journal, 60, no. 4, 2008: 637-654.

Bonate, Liazzat. "Muslims of Northern Mozambique and the Liberation Movements." Social Dynamics, 35, no. 2, 2009: 280-294-

Bonate, Liazzat. "Islam in Northern Mozambique: A Historical Overview." History Compass 8, no. 7 (2010): 573-593.

Borges Coelho, João Paulo. "Uneasy Shores: The Indian Ocean and the Challenges to SADC's Maritime Security." Paper presented to SADSEM-FES Annual Regional Security Dialogue on Security Cooperation in Southern Africa, Maputo, 27-28 October, 2011.

Boyer-Rossol, Klara. "De Morima à Morondava: contribution à l'étude des makoa de l'ouest de Madagascar au XIXe siècle." In Madagascar et l'Afrique: Entre identité insulaire et appartenances historiques edited by Didier Nativel et Faranirina V. Rajaonah, 183-207. Paris: Karthala, 2007.

Breckenridge, Keith. "Marikana and the Limits of Biopolitics: Themes in the Recent Scholarship of South African Mining." Africa, 84, no. 1 (2014), 151-161.

Buur, Lars and Helene Kyed, "State Recognition of Traditional Authorities in Mozambique." Discussion Paper 28. Uppsala, Nordic Africa Institute, 2005.

Cabrita, João M. Mozambique: The Tortuous Road to Democracy. Basingstoke: Palgrave, 2000. 
Cahen, Michel, Philippe Waniez and Violette Brustlein, "Pour un atlas social et cultural de Mozambique." Lusotopie, 1, 2002: 305-362.

Capela, José. O Tráfico de Escravos nos Portos de Moçambique, 1733-1904. Porto: Edições Afrontamento, 2002.

CEDAW, "Shadow Report: Stage of Implementation of the CEDAW [Convention on the Elimination of All Forms of Discrimination Against Women] in Mozambique. " Maputo, 2007.

Chatterjee, Partha. The Politics of the Governed: Reflections on Popular Politics in Most of the World. New York: Columbia University Press, [2004] 2006.

Cobbing, Julian. "The Mfecane as Alibi: Thoughts on Dithakong and Mbolombo." Journal of African History 29 (1988): 487-519.

Declich, Francesca. "'Gendered Narratives', History and Identity: Two Centuries along the Juba River among the Zigula and Shanbara." History in Africa 22 (1995), 93-122.

Declich, Francesca. "Transmission of Muslim Practices and Women's Agency in Ibo Island and Pemba (Mozambique)." Journal of Eastern African Studies 7, no. 4 (2013): 588-606.

Desai, Ashwin and Goolam Vahed. Inside Indenture: A South African Story, 1860-1914. Durban: Madiba Publishers, 2010.

Diouf, Mamadou, ed. Tolerance, Democracy and Sufis in Senegal. New York: Columbia University Press, 2013.

Etherington, Norman. The Great Treks: The Transformation of Southern Africa, 18151854. Harlow: Pearson Education. 
Frederiksen, Bodil Folke. "Mungiki and Vernacular Organization and Political Society in Kenya," Development and Change, 41, no. 6 (2010), 1065-1089.

Green, Nile. Bombay Islam: The Religious Economy of the West Indian Ocean, 1840-1915. Cambridge: Cambridge University Press, 2011.

Hafkin, Nancy Jane. "Trade, Society, and Politics in Northern Mozambique, c. 17531913." PhD diss., Boston University, 1973.

Kaarsholm, Preben. "Transnational Islam and Public-Sphere Dynamics in KwaZuluNatal: Rethinking South Africa's Place in the Indian Ocean World." Africa 81, no. 1 (2011): 108-131.

Kaarsholm, Preben. "Diaspora or Transnational Citizens? Indian Ocean Networks and Changing Multiculturalisms in South Africa." Social Dynamics, 38, no. 3 (2012), 454-466.

Kaarsholm, Preben. "Africa Globalized? Multipolarity and the Paradoxes of Time-Space Compression." In African Dynamics in a Multipolar World, edited by Ulf Engel and Manuel João Ramos, 144-153. Leiden: Brill, 2013.

Kaarsholm, Preben. "Zanzibaris or Amakhuwa? Sufi Networks in South Africa, Mozambique and the Indian Ocean." Journal of African History 55, no. 2 (2014): 191-210.

Khouri, Nicole and Joana Pereira Leite, "Indians of Eastern Africa and Colonizations." Lusotopie, 15(1) (2008): 29-35.

Khouri, Nicole and Joana Pereira Leite, eds. Khojas Ismaïli : Du Mozambique colonial à la globalisation. Paris: L'Harmattan, 2014.

Landau, Loren. "African Urbanization and the Meaning of Belonging." In Violence and Xenophobia in South Africa: Developing Consensus and Moving to Action, edited by Adrian Hadland, 44-63. Pretoria: HSRC, 2008. 
Machado, Pedro. Ocean of Trade: South Asian Merchants, Africa and the Indian Ocean, $c$. 1750-1850. Cambridge: Cambridge University Press, 2014.

Melo, António. "A Diáspora Ismaelita: Preparação e 'Partida', Vivências da Migração dos Anos 1970." Lusotopie XV, no. 1 (2008), 97-102.

Misgun, Biniam. "Foreign Migrants in the Inner City of Durban." In Undressing Durban, edited by Rob Pattman and Sultan Khan, 92-100. Durban: Madiba Publishers.

Moosa, Ebrahim. "Muslim Family Law in South Africa: Paradoxes and Ironies." In Muslim Family Law in Sub-Saharan Africa: Colonial Legacies and Post-Colonial Challenges, edited by Shamil Jeppie, Ebrahim Moosa and Richard Roberts, 331-354. Amsterdam: Amsterdam University Press, 2010.

Morier-Genoud, Eric. "A Prospect of Secularization? Muslims and Political Power in Mozambique Today." Journal for Islamic Studies 27 (2007), 240-275.

Newitt, Malyn. A History of Mozambique. London: Hurst, [1995] 2009.

Ntsebeza, Lungisile, "Traditional Authorities and Democracy: Are We Back to Apartheid?" In The Fate of the Eastern Cape: History, Politics and Social Policy, edited by Greg Ruiters, 75-92. Pietermaritzburg: University of KwaZulu Natal Press, 2011

Nuotio, Hanni, "The Dance that is not Danced, the Song thatis not Sung: Zanzibari Women in the Maulidi Ritual", in The Global Worlds of the Swahili: Interfaces of Islam, Identity and Space in 19th and 20th-Century East Africa, edited by Roman Loimeier and Rüdiger Seesemann, 187-208. Berlin: Lit Verlag, 2007.

Pearson, Michael, The Indian Ocean. London: Routledge, 2003.

Pereira-Bastos, Susana. "Indian Transnationalisms in Colonial and Postcolonial Mozambique," Stichproben. Wiener Zeitschrift für kritische Afrikastudien, 5, no. 8 (2005), 277-306. 
Pereira Leite, Joana, Nicole Khouri and Maria José Mascarenhas. "Les departs des Ismailis du Mozambique: Réflexions sur le départ d'une communauté et sa relation au secret." CEsA Documento de Trabalho 91. Lisbon: Centro de Estudos sobre África e do Desenvolvimento, 2011.

Pereira Leite, Joana and Nicole Khouri. "História Social e Económica dos Ismailis de Moçambique - século XX". CEsA Documento de Trabalho 92. Lisbon: Centro de Estudos sobre África e do Desenvolvimento, 2011.

Pouwels, Randall L. Horn and Crescent: Cultural Change and Traditional Islam on the East African Coast, 800-1900. Cambridge: Cambridge University Press, 1987.

Sadouni, Samadia, "Somalis in Johannesburg : Muslim Transformations of the City." In Topographies of Faith: Religion in Urban Spaces, edited by Irene Becci, Marian Burchardt et Jose Casanova. Leiden: Brill, 2013: 45-59.

Sadouni, Samadia. "Playing Global: The Religious Adaptation of Indian and Smali Muslims to Racial Hierarchies and Discrimination in South Africa," Global Networks, 14, no. 3 (2014), 383-400.

Simone, T. Abdou Maliqalim. "Advantageous Marginalities: A South African Critique of the Islamic Movement in Sudan." Chap. 9 in In Whose Image? Political Islam and Urban Practices in Sudan. Chicago: University of Chicago Press, 1994.

Southall, Roger. Liberation Movements in Power: Party and State in Southern Africa. Woodbridge: James Currey/Boydell and Brewer, 2013.

Swaleh, Kadara. "Islamic Proselytising between Lamu and Mozambique: The Case of Kizingitini Village." Social Dynamics 38, no. 3, 398-418.

Tayob, Abdulkader. Islamic Resurgence in South Africa: The Muslim Youth Movement. Cape Town: UCT Press, 1995. 
Tayob, Abdulkader. Islam in South Africa: Mosques, Imams and Sermons. Gainsville: University Press of Florida, 1999.

Tayob, Abdulkader, "Muslim Publics: Contents and Discontents." Journal for Islamic Studies 27 (2007): 1-15.

Tocqueville, Alexis de. Democracy in America and Two Other Essays on America. London: Penguin Books, [1835-1840] 2003.

Vahed, Goolam. "Constructions of Community and Identity among Indians in Colonial Natal, 1860-1910: The Role of the Muharram Festival." Journal of African History 43, no. 1 (2002): 77-93.

Vahed, Goolam. "Contesting 'Orthodoxy': The Tablighi-Sunni Conflict among South African Muslims in the 1970s and 1980s." Journal of Muslim Minority Affairs 23, no. 2 (2003): 315-336.

Vahed, Goolam, "Islam in the Public Sphere in Post-Apartheid South Africa: Propspects and Challenges". Journal for Islamic Studies 27 (2007): 116-149.

Vahed, Goolam. Ahmed Deedat: The Man and His Mission. Durban: Islamic Propagation Centre International, 2013.

Vahed, Goolam. "Family, Gender, and Mobility amongst Passenger Migrants into Colonial Natal: The Story of Moosa Hajee Cassim (c. 1840s-1921)", forthcoming in Journal of Southern African Studies 42, no. 3 (2016).

Vahed, Goolam and Shamil Jeppie, "Multiple Communities: Muslims in Post-Apartheid Soutyh Africa", in State of the Nation: South Africa 2004-2005, ed. by John Daniel, Roger Southall and Jessica Lutchman, 252-286. Cape Town: HSRC Press, 2005.

Worden, Nigel. Slavery in Dutch South Africa. Cambridge: Cambridge University Press, 1985. 
Worden, Nigel. "Indian Ocean Slaves in Cape Town, 1695-1807." Forthcoming in Journal of Southern African Studies 42, no. 3 (2016).

\section{APPENDIX 1}

National assembly election results between 1994 and 2014:63

1994:

Mozambique:

FRELIMO: $\quad 44.33 \%$

RENAMO: $\quad 37.78 \%$

South Africa:

ANC:

$62.65 \%$

NP:

$20.39 \%$

IFP:

$10.54 \%$

1999:

Mozambique:

FRELIMO: $\quad 48.54 \%$

RENAMO: $\quad 38.81 \%$

South Africa:

ANC:

$66.35 \%$

DP:

$9.56 \%$

IFP:

$8.58 \%$

2004:

Mozambique:

FRELIMO: $\quad 63.03 \%$

RENAMO: $\quad 29.73 \%$

63 Election results drawn from: South Africa 1994, 1999, 2004, 2009 and 2014: Manuel ÁlvarezRivera, Election Resources on the Internet: General Elections in the Republic of South Africa http://electionresources.org/za/ (accessed 30 November 2014); Mozambique 1994, 199, 2004 and 2009: African Elections Database, Elections in Mozambique -

http://africanelections.tripod.com/mz.html (accessed 30 November 2014); Mozambique 2014: Mozambique News Agency, AIM Report 494, 31 October 2014 -

http://www.poptel.org.uk/mozambique-news/newsletter/aim494.html (accessed 30 November 2014). 
South Africa:

$\begin{array}{ll}\text { ANC: } & 69.69 \% \\ \text { DA: } & 12.37 \% \\ \text { IFP: } & 6.97 \%\end{array}$

2009:

Mozambique:

FRELIMO: $\quad 74.66 \%$

RENAMO: $17.68 \%$

MDM: $\quad 3.93 \%$

South Africa:

ANC:

$65.9 \%$

DA:

$16.66 \%$

COPE:

$7.42 \%$

IFP:

$4.55 \%$

2014:

Mozambique:

FRELIMO: $\quad 55.93 \%$

RENAMO: $\quad 32.46 \%$

MDM: $\quad 8.35 \%$

South Africa:

ANC:

$62.15 \%$

DA:

$22.23 \%$

EFF:

$6.35 \%$

IFP:

$2.40 \%$

\section{APPENDIX 2}

Map of Muslim population in Mozambique in 1997:64

64 Map drawn from: Michel Cahen, Philippe Waniez and Violette Brustlein, "Pour un atlas social et cultural de Mozambique", Lusotopie, 1, 2002: 342. 


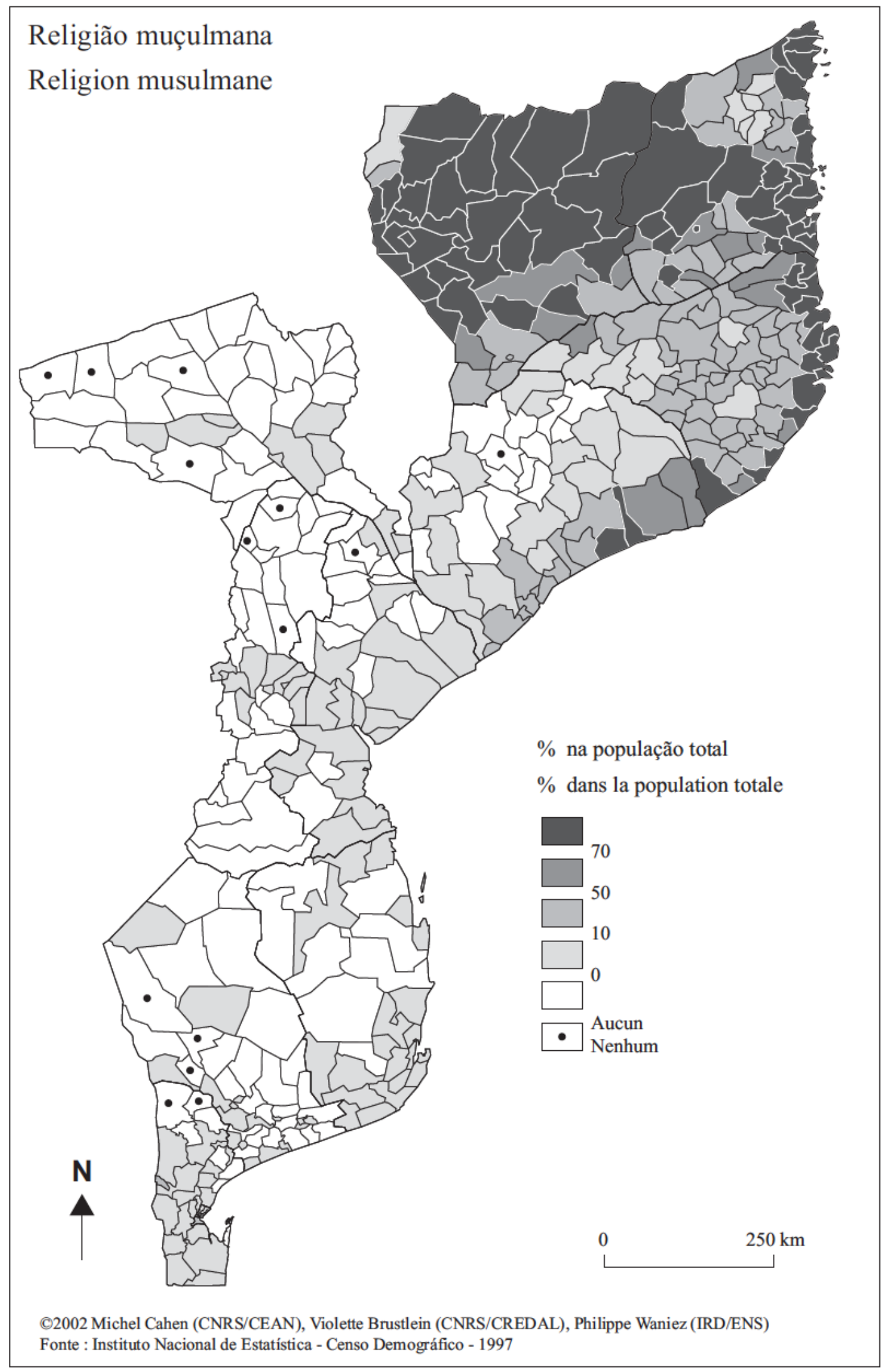

